\title{
The Incidence of Sinus Crista Galli in Children and Adults. A Computerized Tomography Study
}

\author{
La Incidencia del Sinus Crista Galli en Niños y Adultos. \\ Un Estudio de Tomografía Computarizada
}

Ayfer Metin Tellioglu' ${ }^{1}$ \& Yasemin Polat ${ }^{2}$

\begin{abstract}
METIN, T. A. \& POLAT, Y. The incidence of sinus crista galli in children and adults. A computerized tomography study. Int. J. Morphol., 37(2):735-738, 2019.

SUMMARY: The pneumatization area in the crista galli region of the ethmoid bone can be called Sinus Crista Galli (SCG). The authors would like to recommend the terminology as sinus crista galli for pneumatized crista galli. Our aims in this study are to determine SCG on three dimensional Computerized Tomography (CT) images, to investigate its frequency, dimension and to emphasize their clinical significance in children and adults. A total of 360 adult images (160 female, 200 male) and 68(43 female, 25 male) pediatric images were examined. The presence SCG was recorded with axial and coronal paranasal sinus CT images. The height, width, anterposterior diameter of the sinus was measured. All the data we obtained from this study were analyzed using the SPSS 18.0 program. Descriptive statistics are shown as mean \pm Sdt. Sinus crista galli was found in 17 examined images of the 360 (4.72\%) in adult group. Chronic pansinusitis was detected in 7 of 17 cases. Frontal sinusitis findings were detected in 7 cases. Sinusitis was not observed in 3 cases. The incidence of SCG was found in 4 pediatric images out of 68 (5.88 \%). In 1 out of 4 cases, infection was detected in SCG. We did not observe SCG in the pediatric group with 0-7 years of age. Sinus crista galli was found at low rates in adult and pediatric age group. However; relationship was found between these variation and chronic rhinosinusitis. Additionally, detection of SCG in paranasal sinus CT can be provided better results and reduce complications in anterior cranial fossa surgery.
\end{abstract}

KEY WORDS: Sinus crista galli; Anatomy; Computed tomography.

\section{INTRODUCTION}

The ethmoid bone consists of four parts: horizontal (cribriform) plate, vertical (perpendicular) plate, two lateral masses (labyrinths). The crista galli is a perpendicular projection of the cribriform plate of the ethmoid into the endocranial cavity. The crista galli is a thick, midline, smooth triangular process arising from the superior surface of the ethmoid bone, projecting into the anterior cranial fossa (White et al., 2012). The pneumatization area in the crista galli region of the ethmoid bone is called sinus crista galli (SCG), which is a part of the ethmoid bone embryologically. However, studies have reported that crista galli pneumatization is associated with the frontal sinus (Som et al., 2009; Kamala et al., 2016; Mladina et al., 2017).

It is easier to identify these variation due to the development of imaging methods. Nowadays, computed tomography(CT) is frequently used in the evaluation of patients with paranasal sinusitis. CT provides excellent anatomical soft tissue and bony details, objective evidence for the diagnosis and staging, and an important "roadmap" to paranasal sinus anatomy. CT scan of paranasal sinuses play a key role in the preoperative evaluation of patients undergoing endoscopic sinus surgeries (ESS) for chronic rhinosinusitis (Rózyo-Kalinowska et al., 2003).

The dimensions of these structures are generally not significant when compared to other paranasal sinus structures. However, SGC may be infected due to their connection with other sinuses and may cause chronic infection (Socher et al., 2013). In addition, especially the crista galli is an important landmark in the endoscopic sinus surgery and the endoscopic skull-base surgery. Crista galli, an important surgical boundary used when performing the endoscopic transcribriform approach (Lee et al., 2011). The pneumatization area of the crista galli may have important implications for both instrumentation

\footnotetext{
${ }^{1}$ Adnan Menderes University, Faculty of Medicine, Department of Anatomy, Aydin, Turkey.

${ }^{2}$ Adnan Menderes University, Faculty of Medicine, Department of Radiology, Aydin, Turkey.
} 
and the safe dural access in the endoscopic skull-base surgery.

For these reasons, we aimed to determine the frequency and dimensions of the sinus crista galli gathering detailed data from paranasal computerized tomography (CT) images.

\section{MATERIAL AND METHOD}

The study protocol was approved by the Human Ethics Committee of Adnan Menderes University, Turkey. Subjects' data were collected from the patients referred to the radiology department between January 2016 - January 2018. Images were evaluated retrospectively. Demographic information of the patients (age, gender) were assessed from their medical files. Paranasal sinus fractures, face deformity, inappropriate scans and turbid images were among the exclusion criteria. We didn't perform any extra imaging for these patients. A 128 detector 160 slice CT System (Aquilion Prime, Toshiba Medical, Systems, Otawara,Japan) was used and images were transferred to a work station that had direct connection with the CT console. CT examinations of all chosen subjects had been performed with high-resolution parameters $(80 \times 0,5 \mathrm{~mm}$ detector collimation, 2- $\mathrm{mm}$ slice section thickness, 120); therefore, they were suitable for excellent VR and MPR processes. We assessed non-contrast and contrast $\mathrm{CT}$ images.

Total of 360 (160 female, 200 male) adult patients whose ages ranging from 18-85 (mean 42,93) were analyzed. Additionally, a total of 68 children were included in this study. There were 25 male and 43 female with ages ranging from 2 to 18 years (mean $12.7 \pm 3.8$ ). The presence of sinus crista gali was recorded with axial and coronal paranasal sinus CT images. In addition, a curser was placed in the Crista galli lumen and its density was measured. Values below -100 were evaluated as air density.

The height of the sinusus was measured with coronal paranasal sinus CT images and anterior-posterior and width diameter of the sinusus were measured with axial paranasal sinus CT images (Figs. 1 and 2).

Statistical analysis: All data obtained were analysed using SPSS 18.0 software. The frequencies of the sinus were found using frequency analysis. Compliance of the normal distribution of data were analysed by Kolmogorov-Smirnov test. Because all variables were normally distributed, descriptive statistics were shown as mean \pm standart deviation (Std).

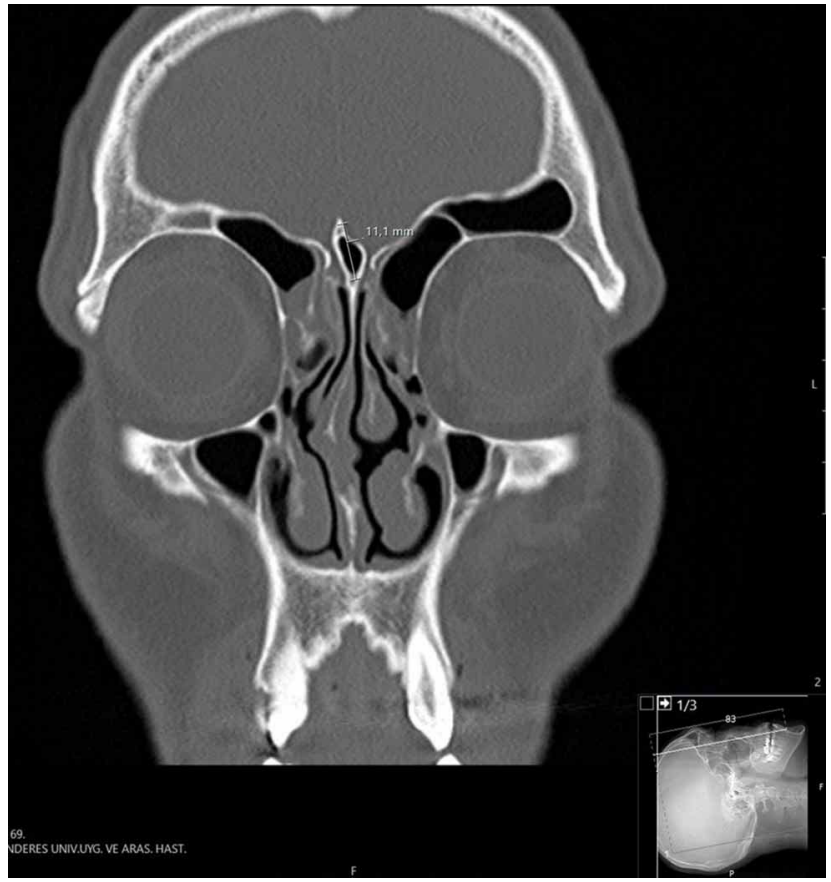

Fig. 1. Sinus crista galli on coronal plane and height measurement.

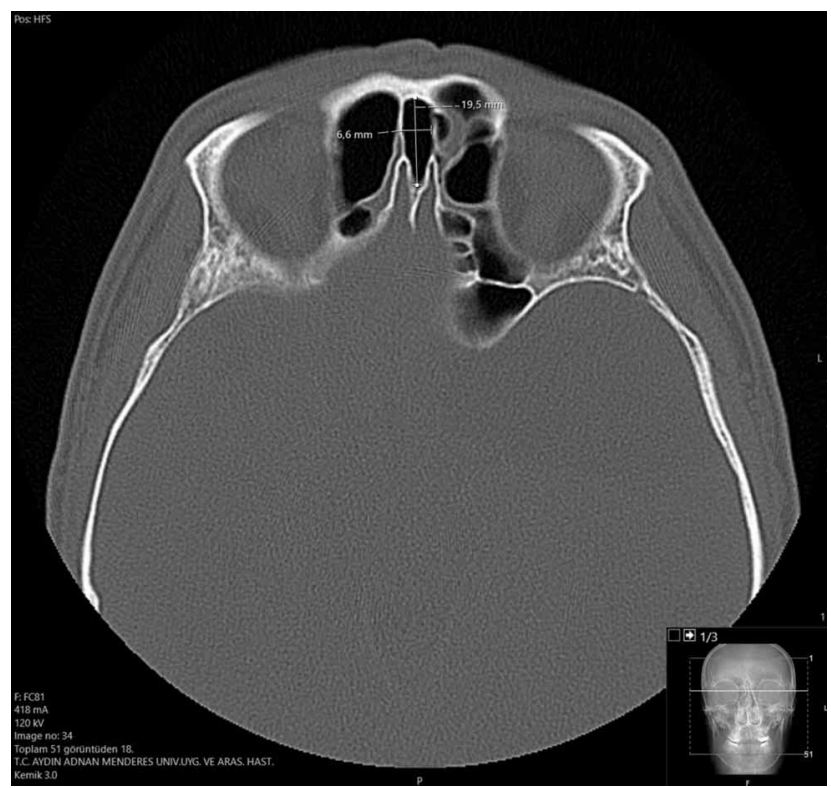

Fig. 2. Sinus crista galli on axial plane and anterior-posterior and width measurements.

\section{RESULTS}

The adult group of the study consisted of 360 images. 160 of the images belonged to females and 200 belonged to males. The average age of the individuals whose images were used is 42,93 (18-85years old). 
Sinus Crista galli was detected in 17 of the 360 examined images in adults. Chronic pansinusitis was detected in 7 of 17 cases.Frontal sinusitis findings were detected in 7 cases.Sinusitis was not observed in 3 cases. Especially in patients with pansinusitis was accompanied by infected SCG (Fig. 3).

Additionally, a total of 68 children were included in this study. There were 25 male and 43 female with ages ranging from 2 to 18 years (mean $12.7 \pm 3.8$ ). $S C G$ was found in 4 out of the $68(5.88 \%)$. images in the pediatric group. In 1 out of 4 cases, infection was detected in SCG. We did not observe SCG in the pediatric group with 0-7 years of age.

SCG minimum and maximum dimensions were: width; 2,2-6,9 mm, height; 7,8-14,2 mm, anterior-posterior diameter; 6,6-19,3 mm, respectively. The dimensions of SCG were: width; $4,24 \pm 1,23 \mathrm{~mm}$, height; $11,10 \pm 1,87 \mathrm{~mm}$, anterior-posterior diameter; $11,15 \pm 3,71$, respectively. According to student $t$ test results, in comparison with gender groups; there was no statistically significant difference between width, height and anterior-posterior diameter measurements ( $p>0,05)$.

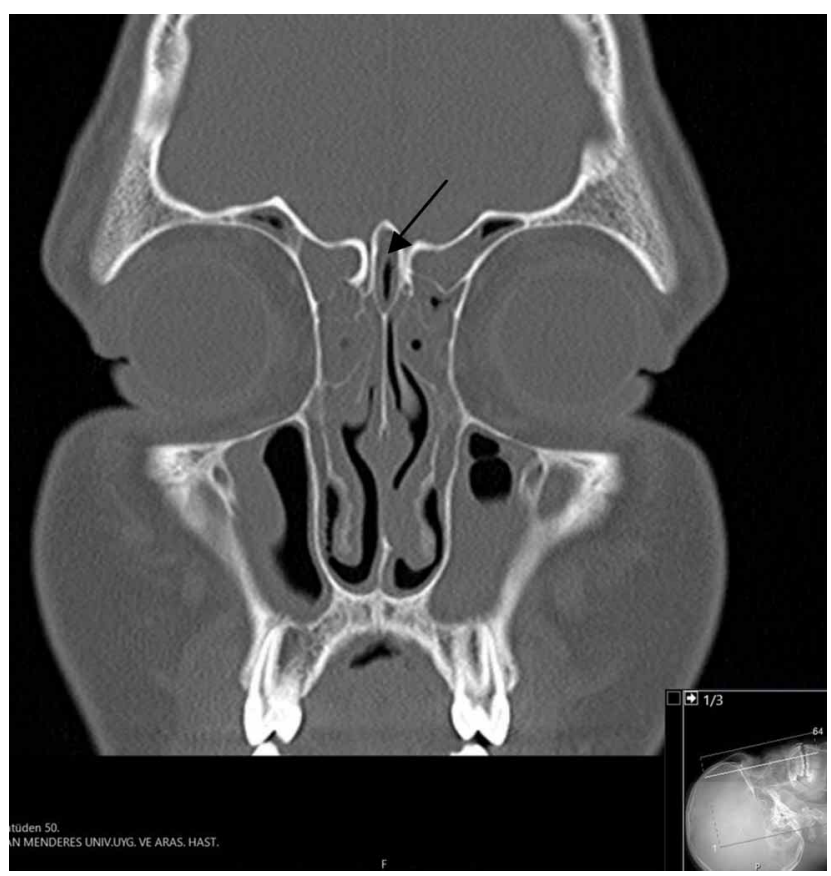

Fig. 3. Infected sinus crista galli.

\section{DISCUSSION}

In our study, SCG incidence was found $4.72 \%$ in adult group and $5.88 \%$ in pediatric group. We did not observe SCG in the pediatric group with 0-7 years of age. It is known that the developmental process of paranasal sinuses is almost completed after 6-8 years of age. Due to these reasons, the frequency of anatomic variation increases after these ages mentioned above.

Different ratios of the SCG incidences were found in the previous studies (Al-Qudah (2010) 31/110 (28\%), Thimmappa et al. (2014) 28/100 (28\%), Manea \& Mladina (2016) 59/196 (30.1\%), Kaygusuz et al. (2014) 13/65 (20 $\%)$, Mladina et al. 198/527 (37.5\%). In the study of Som et al., the incidence of SCG in adults was found to be $26 / 200$ (13\%), while the incidence of SCG in pediatric group (7-12 years of age) was 4/79. However, they did not observe SCG in the group with 0-7 yeas of age (Som et al.). Palabiyik (2018) the incidence of SCG in pediatric grups was found to be $1.1 \%$. The different ratios of SCG found in the literature regarding the anatomic variations may be due to the differences of the evaluation of the data, the sample size, the analysis of the methods and the anatomic definition of the terms in the study. According to us that racial, sex and agerelated differences may also affect the results. Moreover, it is important that the images are evaluated by a radiologist. In our study, all images were evaluated by both radiologist and anatomy specialist.

The crista galli is an important surgical boundary for the endoscopic transcribriform approach (Lee et al.). Cobzeanu et al. (2014) divided crista galli in three groups considering its relationships with cribriform lamina of the ethmoid bone: type I -crista galli situated entirely above the lamina cribriformis, type II - crista galli situated less than 1/ 2 of its height under the lamina cribriformis, type III - crista galli situated more than $1 / 2$ of its height under the lamina cribriformis. SCG was found in all three types of crista galli written above, but in different proportions: pneumatized type I - 9/205 (4.39\%) cases; pneumatized type II - 27/205 (13.17 $\%$ ) cases; pneumatized type III - 11/205 (5.36 \%) cases. In our study, we did not make a typing of the localization of Crista galli. but our results are similar to this study.

Because of the connection of SCG with frontal sinus and frontal recessus, the researchers emphasized its important role in the formation of chronic sinusitis and mucosel. In the study of Manea \& Mladina, pneumatization of crista galli was found in $30.1 \%$ of chronic rhinosinusit patients. Partial or complete opacification on CT scan of the pneumatized crista galli was found in $33.6 \%$ of cases with inflammatory characteristics similar to chronic rhinosinusitis. Socher et al. shared 3 case reports with SCG infections treated with endoscopic sinus surgery. The researchers noticed that SCG may also become infected in the cases with chronic rhinosinusitis. They demonstrated that the patients who did not respond to the drug therapy could be treated safely and 
effectively with endoscopic sinus surgery. In our study, chronic rhinosinusitis was found in most of the cases.

Finally, SCG is the sinonasal anatomic variations in the ethmoid bone. In our study, sinus crista galli was found at low rates in adult and pediatric age group. However; significant relationship was found between these variations and sinusitis. The localizations and dimensions of SCG is directly porportional to the paranasal sinus infections. The identification of these variations by radiologists is very critical since it may help diagnosing chronic and undetermined sinusitis and also an important detail for the surgeon in endoscopic sinus surgery approach.

METIN, T. A. \& POLAT, Y. La incidencia del sinus crista galli en niños y adultos; Un estudio de tomografía computarizada. Int. J. Morphol., 37(2):735-738, 2019.

RESUMEN: El área de neumatización en la crista galli del etmoides se puede denominar sinus crista galli (SCG). Los autores recomiendan incluir en la terminología anatómica el término sinus crista galli para la crista galli neumatizada. Los objetivos del estudio fueron determinar la SCG en imágenes tridimensionales de tomografía computarizada (TC), investigar su frecuencia, dimensión y enfatizar su importancia clínica en niños y adultos. Se examinaron un total de 360 imágenes de adultos (160 mujeres, 200 hombres) y 68 (43 mujeres, 25 hombres) en imágenes pediátricas. La presencia de SCG se registró con imágenes de tomografía axial y axial del seno paranasal. Se midió la altura, anchura y diámetro anteroposterior del seno del proceso crista galli. Todos los datos obtenidos se analizaron mediante el programa SPSS 18.0. Las estadísticas descriptivas se muestran como media \pm DS. El seno crista galli se encontró en 17/360 (4,72\%) de las imágenes examinadas en el grupo de adultos. Se detectó pansinusitis crónica en 7 de 17 casos. Se detectaron hallazgos de sinusitis frontal en 7 casos. Sinusitis no se observó en 3 casos. La incidencia de SCG se encontró en 4 imágenes pediátricas de 68 (5,88 \%). En 1 de cada 4 casos, se detectó infección en SCG. No observamos SCG en el grupo pediátrico con 0-7 años de edad. El seno crista galli se encontró en bajas tasas en adultos y en niños. Sin embargo, se encontró relación entre estas variaciones y la rinosinusitis crónica. Además, la detección de SCG en la tomografía computarizada del seno paranasal puede proporcionar mejores resultados y reducir las complicaciones en la cirugía de la fosa craneal anterior.

PALABRAS CLAVE: Sinus crista galli; Anatomía; Tomografía computarizada.

\section{REFERENCES}

Al-Qudah, M. A. Anatomical varıatıons in sino-nasal region: a computer tomography (CT) study. Jordan Med. J., 44(3):290-7, 2010.

Cobzeanu, M. D.; Bâldea, V.; Bâldea, M. C.; Vonica, P. S. \& Cobzeanu, B.
M. The anatomo-radiological study of unusual extrasinusal pneumatizations: superior and supreme turbinate, crista galli process, uncinate process. Rom. J. Morphol. Embryol., 55(3 Suppl.):1099-104, 2014.

Kamala, E.; Vijaya Shanmugam, U.; Gugapriya, T. S. \& Vinay Kumar, N. A computerized tomographic study of morphology and pneumatization of crista galli. Int. J. Anat. Res., 4(2):2429-33, 2016.

Kaygusuz, A.; Haksever, M.; Akduman, D.; Aslan, S. \& Sayar, Z. Sinonasal anatomical variations: their relationship with chronic rhinosinusitis and effect on the severity of disease-a computerized tomography assisted anatomical and clinical study. Indian J. Otolaryngol. Head Neck Surg., 66(3):260-6, 2014.

Lee, J. M.; Ransom, E.; Lee, J. Y.; Palmer, J. N. \& Chiu, A. G. Endoscopic anterior skull base surgery: intraoperative considerations of the crista galli. Skull Base, 21(2):83-6, 2011.

Manea, C. \& Mladina, R. Crista galli sinusitis - a radiological impression or a real clinical entity. Rom. J. Rhinol., 6(23):167-71, 2016.

Mladina, R.; Antunovic, R.; Cingi, C.; Muluk, N. B.; Skitarelic, N. \& Malic, M. An anatomical study of pneumatized crista galli. Neurosurg. Rev., 40(4):671-8, 2017.

Palabiyik, F. Imaging of the anatomic variations and dangerous areas of the paranasal sinuses and nasal cavity in pediatric patients. I. K. S. S. T. Derg., 10(1):36-42, 2018.

Rózyo-Kalinowska, I.; Jedrzejewski, G. \& Burdan, F. Types of ethmoid sinus morphology on the basis of computed tomography examination. Folia Morphol. (Warsz), 62(4):407-9, 2003.

Socher, J. A.; Santos, P. G.; Correa, V. C. \& Silva, L. C. B. Endoscopic surgery in the treatment of crista galli pneumatization evolving with localizated frontal headaches. Int. Arch. Otorhinolaryngol., 17(3):24650, 2013.

Som, P. M.; Park, E. E.; Naidich, T. P. \& Lawson, W. Crista galli pneumatization is an extension of the adjacent frontal sinuses. A. J. N. R. Am. J. Neuroradiol., 30(1):31-3, 2009

Thimmappa, T. D.; Amith, P.; Nagaraj, M.; Harsha, K. N.; Gangadhar, K. S. \& Azeem, A. Anatomical variations of sinonasal region: a CT scan study. Int. J. Res. Med. Sci., 2(4):1441-5, 2014.

White, T. D.; Black, M. T. \& Folkens, P. A. Human Osteology. $3^{\text {rd }}$ ed. Amsterdam, Academic Press, 2012.

Corresponding author:

Prof. Dr. Ayfer Metin Telllioglu

Adnan Menderes University

Faculty of Medicine

Department of Anatomy.

9100 Aydin

TURKEY

Email: ayfertellioglu@yahoo.com

Received: 12-11-2018

Accepted: 04-02-2019 